\title{
Carbohydrates concentration in leaves of potato plants affected by nitrogen fertilization rates $^{1}$
}

\author{
Heder Braun ${ }^{2 *}$, Paulo Cezar Rezende Fontes ${ }^{3}$, Tania Pires da Silva ${ }^{4}$, Fernando Luiz Finger ${ }^{5}$, \\ Paulo Roberto Cecon ${ }^{6}$, Ana Paula Sato Ferreira
}

$10.1590 / 0034-737 X 201663020016$

\begin{abstract}
At poor conditions of nitrogen $(\mathrm{N})$ in the soil, potato plants may accumulate starch in leaves and be indicative of $\mathrm{N}$ nutritional stress. The objective of this work was to determine the effects of $\mathrm{N}$ rates $\left(0,50,100,200\right.$ and $300 \mathrm{~kg} \mathrm{ha}^{-1}$ of N) on the concentrations of carbohydrates (total soluble sugars-TSS, reducing sugars-RS, non-reducing sugars-NRS and starch) in the fourth leaf (FL) of two potato cultivars (Asterix and Atlantic) and their critical levels (CL) associated to the $\mathrm{N}$ fertilization rate necessary to obtain the maximum physical (MPE) and economic (MEE) efficiency of tubers. A randomized block design with four replications was used in both experiments. On day 21 after plant emergence, four FL were collected from four plants. Potatoes plants fertilized with low rates of $\mathrm{N}$ accumulated less TSS in leaves than those properly fertilized. The opposite occurred with content of starch. The cultivars showed similar responses to five doses of $\mathrm{N}$ in relation to contents of starch and TSS. However, the response to the increase in doses of N for RS, NRS and Starch/NRS is cultivar-specific. The correlations between contents of RS, NRS and Starch/NRS with the starch and TSS were dependent on the potato cultivar.
\end{abstract}

Key words: correlation, fourth leaf, Solanum tuberosum L., sugar, starch.

\section{RESUMO}

\section{Teores de carboidratos nas folhas de batata influenciados por doses de nitrogênio}

Em condições de deficiência de nitrogênio $(\mathrm{N})$ no solo, as plantas de batata podem acumular amido nas folhas e ser indicativo de estresse nutricional de N. Determinou-se o efeito de doses de N (0;50;100; 200 e $\left.300 \mathrm{~kg} \mathrm{ha}^{-1}\right)$ sobre os teores de carboidratos (açúcares solúveis totais-AST, açúcares redutores-AR e não redutores-ANR e amido) produzidos na quarta folha $(\mathrm{QF})$ de dois cultivares de batata (Asterix e Atlantic) e seus níveis críticos (NC) associados à dose de N necessária à obtenção da máxima eficiência física (MEF) e econômica (MEE) de tubérculos. Em ambos os experimentos foi utilizado o delineamento em blocos casualizados, com quatro repetições. Aos 21 dias, após a emergência das plantas, foram coletadas quatro QF de quatro plantas. Plantas de batatas que receberam as menores doses de $\mathrm{N}$ acumularam menos AST nas folhas do que aquelas adequadamente nutridas. O oposto ocorreu com o teor de amido. As cultivares apresentaram respostas similares para as cinco doses de N quanto aos teores de amido e AST. Entretanto, é cultivar específica a reposta ao incremento na dose de N para AR, ANR e Amido/ANR. As correlações entre os teores de AR, ANR e Amido/ANR com os teores de amido e de AST são dependentes do cultivar de batata.

Palavras-chave: Solanum tuberosum L., açúcares, amido, quarta folha, correlação.

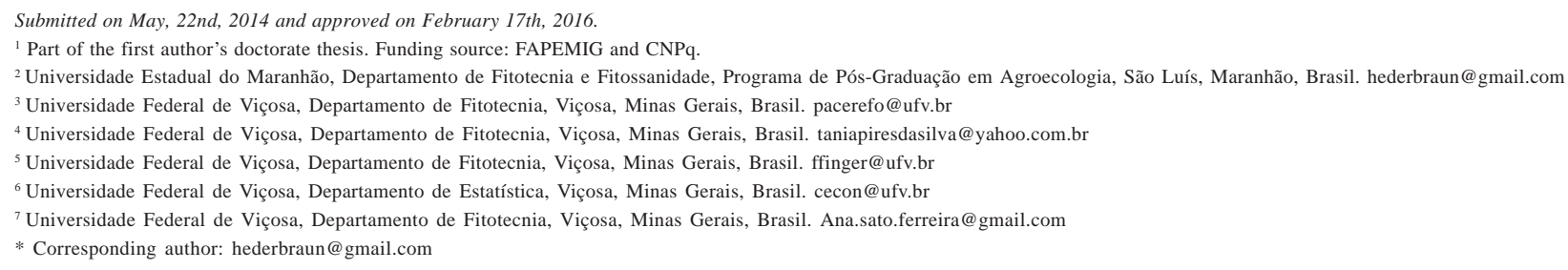




\section{INTRODUCTION}

In potatoes (Solanum tuberosum L.), the metabolisms of carbon $(\mathrm{C})$ and nitrogen $(\mathrm{N})$ need to be coordinated to achieve their optimal growth and development. The strong relationship between carbon and $\mathrm{N}$ strengthens the physiological responses to explain the growth of plants by means of interaction between both of them (Osone et al., 2008). There are two distinct ways where $\mathrm{CO}_{2}$ absorption is reduced when submitted to condition of low N. One is due to the reduction of proteins and enzymes involved in the assimilation of $\mathrm{CO}_{2}$ and the other is due to the fact that $\mathrm{N}$ affects the drain activity when using assimilated carbon at a rate higher than the supply capacity by the source, which results in the accumulation of carbohydrates in the leaves (Chen \& Cheng, 2003).

In potato plants, via photosynthesis, leaves are the major organ responsible for the production of carbohydrates, most commonly, sucrose and starch (Paul \& Foyer, 2001), usually transported and stored in the tubers, where the starch represents 52-80\% of the dry matter (Braun et al., 2010) and the main stored sugars are glucose, fructose and sucrose. Non-structural carbohydrates (hexose, sucrose and starch) may accumulate in the stems of wheat plants (Ruuska et al., 2008) or be remobilized and translocated to other parts in the plant (mainly drains), contributing to the growth and productivity gain (Pan et al., 2011).

In conditions of light, sugars are the primary products of carbon assimilation via photosynthesis (Chen, 2014). In addition, a fraction of the carbon assimilated by photosynthesis is temporarily retained in chloroplasts as starch instead of being converted into sucrose and being exported to the plant growth sites (Niittylä et al., 2004). This temporary starch is degraded overnight to provide continuous supply of sugars that sustains the metabolism in the leaf (Zeeman et al., 2007; Zeeman et al., 2010). The temporary starch produced in the leaves is first degraded into maltose and glucose by hydrolysis and both are exported to the cytoplasm and metabolized in the cytosol (Niittylä et al., 2004). Thus, the main sources of free sugars found in plants are the disaccharides (sucrose and maltose) and monosaccharides (glucose and fructose) (Halford et al., 2011).

Several factors may limit photosynthesis or influence the partition of photoassimilates in the leaves to the tubers (Robredo et al., 2011). One of such factors is the nitrogen stress (Boussadia et al, 2011; Jin et al, 2015.). Besides wheat crop, starch and soluble sugars can accumulate in rice plants (Hirano et al., 2005; Wang et al., 2006) and in grapes (Vitis labrusca L.) (Chen \& Cheng, 2003) with low $\mathrm{N}$ supply. In cassava, total soluble sugars and nonreducing sugars had their contents increased and reducing sugars as well as starch decreased as nitrate supply increased in the solution (Cruz et al., 2003). Yet, Jin et al. (2015) reported that levels of sugars increased in leaves of maize plants as levels of $\mathrm{N}$ increased. On the other hand, it was found in common bean plants, that the accumulation of glucose and starch, at the limiting conditions of N, was approximately the half when compared to normal conditions of N (Jifon \& Wolfe, 2002).

In momentary unfavorable conditions of N, Pan et al. (2011) consider that carbohydrate reserves in branches or stems play an important role in buffering stress. Under these conditions, plants accumulate starch in the leaves, which may be indicative of nitrogen nutritional stress. Thus, there is not much information in the literature of the influence of doses of nitrogen fertilizers on carbohydrate contents produced in leaves of potato cultivars. Similarly, little is known on the correlation between carbohydrates in the leaf with physiological indices and the $\mathrm{N}$ commonly used to evaluate the $\mathrm{N}$ status of the plant. Thus, the objective of this work was to determine the effect of $\mathrm{N}$ on the amount of carbohydrates produced in the fourth leaf of two potato cultivars, and to estimate the critical level of contents of carbohydrates associated with the rate of $\mathrm{N}$ necessary to obtain productions of maximum physical and economic efficiency of tubers of two potato cultivars.

\section{MATERIAL AND METHODS}

The experiments were carried out in the experimental area located at $693 \mathrm{~m}$ above sea level, at $20^{\circ} 45^{\prime} \mathrm{S}$ and $42^{\circ} 51^{\prime}$ W in a Red-Yellow Cambic Podzolic Soil (Embrapa, 2013), Viçosa, state of Minas Gerais. The soil used in the

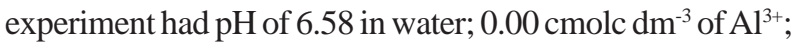
$41.2 \mathrm{mg} \mathrm{dm}^{-3}$ of remaining P; $230 \mathrm{~g} \mathrm{~kg}^{-1}$ of sand; $300 \mathrm{~g} \mathrm{~kg}^{-1}$ of clay and $470 \mathrm{~g} \mathrm{~kg}^{-1}$ of silt. Firstly, deep plowing was carried out in the soil with moldboard plow and two leveling grate passages, with a subsequent furrowing.

Two simultaneous experiments were established, each experiment corresponded to a potato cultivar, Asterix and Atlantic. In each experiment, five doses of $\mathrm{N}$ were applied $\left(0,50,100,200\right.$ and $\left.300 \mathrm{~kg} \mathrm{ha}^{-1} \mathrm{~N}\right)$ in the furrow, at preplanting, using ammonium sulfate. The experiments were conducted in a randomized block design with four replications in plots of $3.0 \times 1.75 \mathrm{~m}$, comprised of 28 plants in four rows, spaced by $0.75 \mathrm{~m}$ and $0.25 \mathrm{~m}$ between plants. The two side rows and one plant at each edge of the central rows were used as borders, totaling 10 useful plants.

The mineral fertilizers together with the $\mathrm{N}$ in the form of ammonium sulfate and carbofuran insecticides were applied in the furrows and mixed with the soil as described in Braun (2012). Certified seed potatoes with about $70 \mathrm{~g}$, previously 
sprouted were used in the study. On day 21 after full plant emergence (DAE), the fourth leaf (FL) was collected from four plants representing each experimental plot. At $22 \mathrm{DAE}$, the plants were hilled by horing solil up around the plant stems (Braun et al., 2010).

Approximately $1.2 \mathrm{~g}$ of leaf fresh weight was collected for the quantification of total soluble sugars (TSS), starch, reducing sugars (RS) and non-reducing (NRS) sugars. After that, the samples were placed in containers containing $80 \%$ of heated ethanol $\left(70{ }^{\circ} \mathrm{C}\right)$ and then the containers remained at $5{ }^{\circ} \mathrm{C}$ until extraction and quantification of carbohydrates. The plant material was homogenized in $80 \%$ ethanol, followed by centrifugation at 2,000 rpm for 10 minutes. Extraction and centrifugation were repeated three times and the supernatants were combined for the determination of total and reducing sugars. Total soluble sugars were determined by the phenol-sulfuric method (Dubois et al., 1956) and quantified by Somogy-Nelson method (Nelson, 1944). For quantification of sugars, sucrose and glucose standards were used for TSS and RS, respectively.

The residue from extraction of TSS was dried at 70 ${ }^{\circ} \mathrm{C}$, the starch was hydrolyzed in $52 \%$ of perchloric acid for 30 minutes and centrifuged for 10 minutes at 2,000 rpm, according to McCready (1950). The procedure was repeated three times and the supernatants were combined for determination by using the phenol-sulfuric method, as described for the determination of TSS. Content of NRS was estimated by subtracting the RS values from TSS.

The following physiological indices were quantified: specific leaf area plant (SLA, $\mathrm{cm}^{2} \mathrm{~g}^{-1}$ ) and of the fourth leaf (FLSLA, $\mathrm{cm}^{2} \mathrm{~g}^{-1}$ ) and the nutritional indices of N quantified in the fourth leaf (FL) were: $\mathrm{N}$ use efficiency (FLNUE, $\mathrm{g} \mathrm{g}^{-1}$ ); $\mathrm{N}$ content per area (NCFLA, $\mathrm{g} \mathrm{cm}^{-2}$ ); $\mathrm{N}$ concentration (FLN, dag $\mathrm{kg}^{-1}$ ) and $\mathrm{N}$ content (FLNC, dag kg-1) (data not shown as a function of $\mathrm{N}$ doses). The physiological and nitrogen indices as well as the commercial productivity $\left(\mathrm{CP}, \mathrm{t} \mathrm{ha}^{-1}\right)$ were used to perform the correlation analysis with the carbohydrates produced in the fourth leaf for the two potato cultivars and their descriptions are presented in Braun (2012).

To compare the two potato cultivars, joint analysis of variance was performed considering each cultivar an experiment. After completion of the analysis of variance, regardless of the significance of the interaction between doses of $\mathrm{N}$ and cultivars, interactions between factors were unfolded. Then, comparison of the means of the two cultivars within each dose of $\mathrm{N}$ was performed by the test of Tukey $(p<0.05)$. For the quantitative factor, the regression model was adjusted. The adjusted regression models were chosen based on biological sense, on the significance of the regression coefficients $(p<0.10)$ by the
" $t$ " Student test and on the coefficient of determination calculated by the relationship $\left(\mathrm{R}^{2}=\mathrm{SS}_{\text {Regression }} / \mathrm{SS}_{\text {Treatment }}\right)$.

For each cultivar, the critical level of $\mathrm{N}$ was estimated using two doses of $\mathrm{N}$, that is, the dose that provided the maximum physical (MFE) and economic (MEE) efficiency. The $\mathrm{N}$ dose that provided the MFE was obtained by equating to zero the first derivative of the response equation of commercial tuber yield to the $\mathrm{N}$ doses. The dose of $\mathrm{N}$ that provided MEE was obtained by equaling the first derivative of equation response of commercial tuber yield to doses of $\mathrm{N}$ to the relationship between the average price of $\mathrm{N}$ contained in the urea and the price of potatoes $(\mathrm{R} \$ / \mathrm{kg}$ : $\mathrm{R} \$ /$ $\mathrm{kg}$ ). In addition, the values of the physiological and nitrogen indices and the $\mathrm{CP}$ were submitted to simple linear correlation analysis (r) with the values for the carbohydrates produced in the fourth leaf. The statistical software used to perform the analysis was the Sistema para Análises estatísticas e Genéticas (System for Statistical and Genetic Analyses SAEG version 9.1, 2007).

\section{RESULTS AND DISCUSSION}

For Asterix and Atlantic cultivars, the doses of $\mathrm{N}$ had a linear and positive effect on the content of TSS in the four leaf fresh matter, while the content of starch decreased as rates of $\mathrm{N}$ increased, following the quadratic model (Figure 1). That is, at the lowest doses of nitrogen fertilizer added to the soil, leaves of potato cultivars accumulated lower amounts of TSS and greater content of starch than those properly fertilized with $\mathrm{N}$.

In both cultivars, $\mathrm{N}$ rates did not affect values of contents of NRS in the fourth leaf fresh matter. The estimated average values of NRS, followed by the standard error of the mean were $1.96 \pm 0.19$ and $3.95 \pm 0.24 \mathrm{mg} \mathrm{g}^{-1}$ in the fresh mass of the fourth leaf for cultivars Asterix and Atlantic (Table 1). No difference between "Asterix" and "Atlantic" was found in any dose of $\mathrm{N}$ in relation to contents of starch and TSS (Table 1). Depending on the doses of $\mathrm{N}$, the cultivars presented or did not present differences in the variables RS, NRS and starch/NRS (Table 1).

The effect of doses of $\mathrm{N}$ on the content of RS and starch / NRS was specific for potato cultivar. Thus, a positive and linear effect of $\mathrm{N}$ rates on $\mathrm{RS}$ was found for cultivar Asterix and a decreasing quadratic effect was found on starch/NRS for the cultivar Atlantic (Table 2). In addition to the starch accumulation in leaves, at conditions of low $\mathrm{N}$, the relationship starch/NRS is indicative of carbon partitioning in plants, which has increased as doses of $\mathrm{N}$ were reduced (Table 2). The results of this experiment are in agreement with Cruz et al. (2003), who reported that such behavior is due to a deficiency in the capacity of exporting sugar concomitantly to the stimulus for formation of starch in cassava. 
Thus, because of the low capacity of sucrose synthesis associated with the low concentration of inorganic phosphate $(\mathrm{Pi})$ in the chloroplast, triose phosphate produced via Calvin's cycle would be responsible for the deviation of photosynthetically fixed carbon for starch synthesis (Paul \& Foyer, 2001). In this study, this fact would probably be inferred by the significant and negative correlation between NRS and starch $\left(r=-0.83^{*}\right)$ in the Atlantic cultivar (Table 3). However, in the study carried out by Cruz et al. (2003), starch synthesis was verified by the significant and negative correlations of starch contents with NRS $\left(r=-0.36^{*}\right)$ and $\mathrm{Pi}\left(\mathrm{r}=-0.39^{*}\right)$. In addition, these authors reported a significant and positive correlation between the content of starch with RS $\left(r=0.51^{*}\right)$, that is, it is another factor responsible for the synthesis of starch in cassava. Moreover, Paul \& Foyer (2001), reported that the starch synthesis occurs when there is little Pi available in the chloroplast.
For the two potato cultivars, the relationship between the content of starch and TSS was significant and negative. The significance of correlations between the contents of RS, NRS and starch/NRS with contents of starch and TSS relied on the potato cultivar (Table 3 ).

In both potato cultivars, a significant and negative correlation between content of starch and $\mathrm{N}$ in mass basis (NCFL) and area (NCFLA) (Table 3) was found. It was also observed a significant and negative correlation of starch content with the $\mathrm{N}$ content in the fourth leaf (NRFL) in both potato cultivars.

In both potato cultivars, a significant and negative correlation was found between the content of accumulated starch in the leaf and tuber production and the other physiological and nitrogen variables in the leaves, except the specific leaf area of the fourth leaf (SPLAFL) and use efficiency of $\mathrm{N}$ in the fourth leaf (NUEFL), which correlated positively with the starch content. Starch is an insoluble
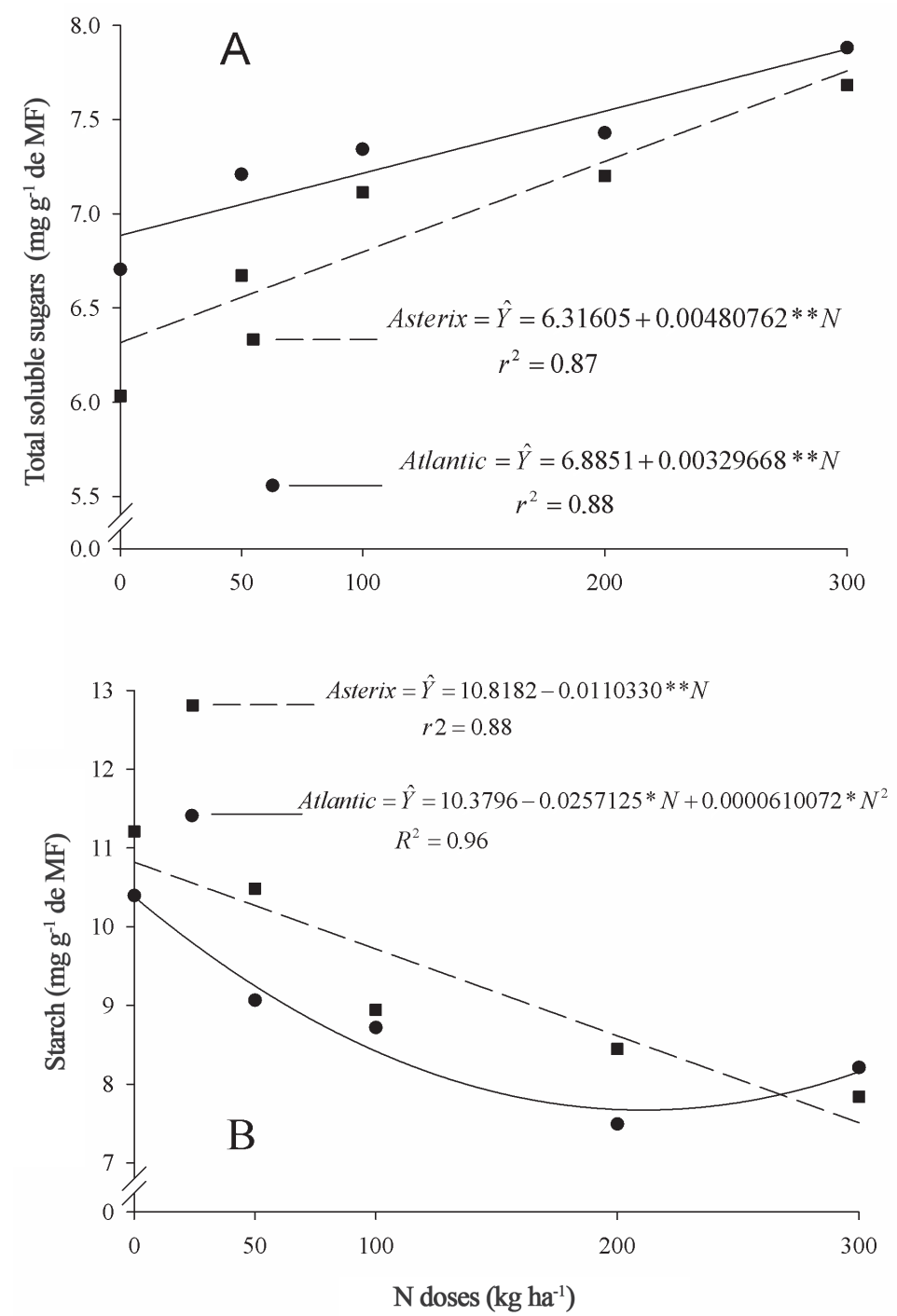

Figure 1: Content of total soluble sugars (A) and starch (B) of cultivars Asterix and Atlantic, according to the doses of N. **: significant by the "te" test $(\mathrm{p}<0.01)$. 
glucan, composed of polymers of amylopectin, amylose and glucose; it is synthesized in the plastids of the "source", via photosynthesis. Plants store starch in the leaves during the day and decomposes it at the following night, which is named temporary starch accumulation. In $\mathrm{C}_{3}$ plants such as potatoes, transitory starch breaking down occurs in two ways, hydrolytic or amylolytic and phosphorolitic ways (Weise et al., 2011). The degraded starch provides substrate for leaf respiration and for the synthesis of sucrose as well as for the export to other growing parts of the plant (Zeeman et al., 2010), mainly for the tubers, in relation to potatoes. When there is a limited capacity by the plant to produce sucrose by photosynthesis, the mechanism of temporary accumulation of starch also acts as carbon storer. So, it is not desirable to have starch accumulation in the leaves but in the tubers where it is the main stored carbohydrate, about 52 to $80 \%$ (Braun et al., 2010).

Plants of both cultivars with severe low $\mathrm{N}\left(0 \mathrm{~kg} \mathrm{ha}^{-1}\right)$ presented higher content of starch in the leaves, 11.21 and $10.39 \mathrm{mg} \mathrm{g}^{-1} \mathrm{FM}$ (Table 1) than those fertilized with the optimal economical dose of $\mathrm{N}$ (8.88 and $7.68 \mathrm{mg} \mathrm{g}^{-1}$ (Table 1 and Figure 1) for Asterix and Atlantic, respectively. That is, $\mathrm{N}$ deficiency decreased the capacity of the "source" in using the produced starch. The capacity of the "source" is decreased when the plants are submitted to N-deficiency condition as well as to the carbon partitioning between different parts of the plant. Accordingly, carbon allocation among the metabolic pathways such as the formation of starch, and formation of sucrose and the glycolysis can be changed.

In a study by Hirano et al. (2005) with rice, starch accumulation was found in leaves of the plants grown in low $\mathrm{N}$ supply. Poor $\mathrm{N}$ conditions reduce the growth of plants and greater amount of carbon can be diverted for starch formation (Paul \& Driscoll, 1997). Stitt (1999) reported that this occurs because $\mathrm{N}$ directly affects starch synthesis, that is, $\mathrm{N}$ affects the key enzyme in starch biosynthesis, which is ADP-glucose pyrophosphorylase. In addition, the activity of sucrose phosphate synthase (SPS) is reduced at limiting $\mathrm{N}$ conditions, which can stimulate starch synthesis. In a study by Chen \& Cheng (2003), when there is excess of starch in the chloroplast, photosynthesis can be seriously affected, and there may be difficulties in the arrival of $\mathrm{CO}_{2}$ to carboxylation sites of Rubisco. These authors reported that in $\mathrm{N}$-limiting conditions, there are reduced amounts of enzymes and proteins involved in assimilation of $\mathrm{CO}_{2}$.

Starch accumulation in leaves of plants exposed to the $\mathrm{N}$-limiting condition indicates unbalance between the "source" and "sink", that is, triose phosphate synthesis rate produced by the plant exceeded its rate of utilization

Table 1: Critical level associated to the $\mathrm{N}$ dose that provided maximum physical (MPE) and economic efficiency (MEE) and the content of starch, total soluble sugar (TSS), reducing sugar (RS) and nonreducing sugar (NRS) and the relationship between starch and NRS (S/NRS), within N doses

\begin{tabular}{|c|c|c|c|c|c|c|c|c|}
\hline \multirow{2}{*}{ Cultivars } & \multirow{2}{*}{ Variables } & \multicolumn{2}{|c|}{ Critical level } & \multicolumn{5}{|c|}{$\mathrm{N}$ doses $\left(\mathrm{kg} \mathrm{ha}^{-1}\right)$} \\
\hline & & MPE & MEE & $\mathbf{0}$ & 50 & 100 & 200 & 300 \\
\hline Asterix & $\operatorname{Starch}\left(\mathrm{mg} \mathrm{g}^{-1}\right)$ & 8.83 & 8.88 & $11.21 \mathrm{~A}^{1}$ & $10.48 \mathrm{~A}$ & $8.94 \mathrm{~A}$ & $8.44 \mathrm{~A}$ & $7.84 \mathrm{~A}$ \\
\hline Atlantic & & 7.67 & 7.68 & $10.39 \mathrm{~A}$ & $9.06 \mathrm{~A}$ & $8.71 \mathrm{~A}$ & $7.49 \mathrm{~A}$ & $8.21 \mathrm{~A}$ \\
\hline Asterix & TSS $\left(\mathrm{mg} \mathrm{g}^{-1}\right)$ & 7.18 & 7.16 & $6.03 \mathrm{~A}$ & $6.67 \mathrm{~A}$ & $7.11 \mathrm{~A}$ & $7.20 \mathrm{~A}$ & $7.68 \mathrm{~A}$ \\
\hline Atlantic & & 7.56 & 7.55 & $6.70 \mathrm{~A}$ & $7.21 \mathrm{~A}$ & $7.34 \mathrm{~A}$ & $7.42 \mathrm{~A}$ & $7.88 \mathrm{~A}$ \\
\hline Asterix & $\mathrm{RS}\left(\mathrm{mg} \mathrm{g}^{-1}\right)$ & 5.22 & 5.20 & $4.25 \mathrm{~A}$ & $4.41 \mathrm{~A}$ & $5.22 \mathrm{~A}$ & $5.28 \mathrm{~A}$ & $5.72 \mathrm{~A}$ \\
\hline Atlantic & & $3.36^{\mathrm{ns}}$ & $3.36^{\mathrm{ns}}$ & $3.29 \mathrm{~A}$ & $3.88 \mathrm{~A}$ & $3.25 \mathrm{~B}$ & $2.99 \mathrm{~B}$ & $3.39 \mathrm{~B}$ \\
\hline Asterix & $\operatorname{NRS}\left(\mathrm{mg} \mathrm{g}^{-1}\right)$ & $1.96^{\mathrm{ns}}$ & $1.96^{\mathrm{ns}}$ & $1.78 \mathrm{~B}$ & $2.25 \mathrm{~A}$ & $1.89 \mathrm{~B}$ & $1.91 \mathrm{~B}$ & $1.96 \mathrm{~B}$ \\
\hline Atlantic & & $3.95^{\mathrm{ns}}$ & $3.95^{\mathrm{ns}}$ & $3.41 \mathrm{~A}$ & $3.36 \mathrm{~A}$ & $4.08 \mathrm{~A}$ & $4.43 \mathrm{~A}$ & $4.48 \mathrm{~A}$ \\
\hline Asterix & Starch/NRS & $6.05^{\text {ns }}$ & $6.05^{\mathrm{ns}}$ & $6.86 \mathrm{~A}$ & $5.47 \mathrm{~A}$ & $6.32 \mathrm{~A}$ & $5.51 \mathrm{~A}$ & $6.10 \mathrm{~A}$ \\
\hline Atlantic & & 1.82 & 1.82 & $3.13 \mathrm{~A}$ & $2.80 \mathrm{~A}$ & $2.16 \mathrm{~B}$ & $1.80 \mathrm{~A}$ & $2.01 \mathrm{~B}$ \\
\hline
\end{tabular}

FM: fresh matter mass; ns: non-significance of $\mathrm{N}$ dose on the analyzed characteristic in each cultivar.

1 For each dependent variable, means followed by the same letter in the column are not statistically different from each other by the test of Tukey $(\mathrm{p}>0.05)$.

Table 2: Content of reducing sugars (RS) and Starch/NRS relationship of cultivars Asterix and Atlantic, according to N doses

\begin{tabular}{lccc}
\hline Variable & Cultivar & Adjusted equation & $\mathbf{R}^{2}$ and $\mathbf{r}^{2}$ \\
\hline $\mathrm{RS}\left(\mathrm{mg} \mathrm{g}^{-1}\right.$ of $\left.\mathrm{FM}\right)$ & Asterix & $\hat{\mathrm{Y}}=4.35026+0.00484082^{*} \mathrm{~N}$ & 0.87 \\
Starch/NRS & Atlantic & $\hat{\mathrm{Y}}=3.20507-0.01264 * \mathrm{~N}+0.0000286898 * \mathrm{~N}^{2}$ & 0.97 \\
\hline
\end{tabular}

FM: fresh matter mass; *: significant by the " $\mathrm{t}$ " test $(\mathrm{p}<0.05)$. 
(Stitt, 1991; Cruz et al., 2003). This indicates damage in the export of the starch from the "source" leaves to growing "drain" organs as well as a stimulus for starch formation in them. This starch accumulation in leaves in limiting conditions of $\mathrm{N}$ is due to the repression of genes associated with the ribulose-1,5 bisphosphate carboxylase/ oxygenase (Rubisco) synthesis, reduced activity of Rubisco and the low concentration of $\mathrm{N}$ in the leaf (Paul \& Driscoll, 1997). Thus, low concentration of $\mathrm{N}$ in leaf tissue both in weight basis (NCFL $\mathrm{g} \mathrm{g}^{-1}$ ) and in the area of the base (NCFLA $\mathrm{g} \mathrm{cm}^{-2}$ ) is indicative of carbohydrate accumulation in leaves of potato cultivars as well as plants with low nitrogen nutritional status.

The lower doses of $\mathrm{N}$ offered to plants had an effect on the allocation of photoassimilates, not only altering the content of starch, but also the total soluble sugar (TSS) in the leaves (Figure 1). In both cultivars, the content of total soluble sugars in the fourth leaf fresh matter increased linearly and positively as doses of $\mathrm{N}$ increased. Thus, plants under treatments with severe deficiency of $\mathrm{N}(0 \mathrm{~kg}$ $\mathrm{ha}^{-1}$ ) presented a lower content of TSS in the leaf fresh mass, 6.03 and $6.7 \mathrm{mg} \mathrm{g}^{-1}$ (Table 1) than those fertilized with the great economical dose of $\mathrm{N}, 7.16$ and $7.55 \mathrm{mg} \mathrm{g}^{-1}$ (Table 1 and Figure 1), for the cultivar Asterix and Atlantic, respectively.

The study conducted by Paul \& Driscoll (1997) reports the accumulation of soluble sugars on leaves of tobacco (Nicotiana tabacum) in N-limiting conditions. According to reports of Wingler et al. (2006), this accumulation of soluble sugars may have been caused due to the reduction of carbon skeletons for the synthesis of amino acids and proteins. On the other hand, Jin et al. (2015) reported that sugar content increased as levels of $\mathrm{N}$ increased. These authors reported the importance of this parameter as an indicator of the physiological changes of the plants.

A positive correlation of NCFLA expressed in $\mathrm{g} \mathrm{cm}^{-2}$, with TSS $(r=0.93 * *, r=0.87 *$ ) was found for cultivars Asterix and Atlantic. However, the correlation between NCFLA with RS $\left(r=0.87^{*} ; r=-0.17^{\mathrm{NS}}\right)$ was significant and positive for the cultivar Asterix, only (Table 3). When conducting a work with grapes (Vitis labrusca L.), Chen \& Cheng (2003) showed an increase in the contents of glucose, fructose and sucrose in relation to the content of $\mathrm{N}$ in the leaf based on area $\left(\mathrm{g} \mathrm{m}^{-2}\right)$. In the present experiment, plant potatoes that received the lowest doses of $\mathrm{N}$, in both cultivars, did not accumulate TSS in the fourth leaf fresh matter (Figure 1). Similar results were obtained by Chen \& Cheng (2003) in N-limiting conditions, in which grapes did not accumulate soluble sugars. Thus, for the optimal growth and development of plants, metabolisms of $\mathrm{C}$ and $\mathrm{N}$ need to be tightly coordinated.

A positive correlation of NCFLA expressed $\mathrm{g} \mathrm{cm}^{-2}$, with AST $(r=0.93 * *, r=0.87 *)$ was found for Asterix and Atlantic cultivars. However, the correlation of NCFLA with $\mathrm{RS}\left(\mathrm{r}=0.87^{*} ; \mathrm{r}=-0.17^{\mathrm{NS}}\right)$ was significant and positive for the Asterix cultivar (Table 3 ). With grapes, (Vitis labrusca L.), Chen \& Cheng (2003) showed that there was increase in levels of glucose, fructose and sucrose in relation to leaf nitrogen content based on area $\left(\mathrm{g} \mathrm{m}^{-2}\right)$. In this study, plant potatoes that received lower doses of $\mathrm{N}$ in both cultivars did not accumulated TSS in fresh matter of the fourth leaf (Figure 1). Similar results were obtained by Chen \& Cheng (2003) in N-limiting conditions, where grapes did not accumulate soluble sugars. Thus, for optimal growth and development of plants, metabolisms of $\mathrm{C}$ and $\mathrm{N}$ need to be tightly coordinated.

Table 3: Correlation of Pearson (r) between carbohydrates and physiological indices: plant specific leaf area and specific leaf area of the fourth leaf (SPLA and SLAFL, $\mathrm{cm}^{2} \mathrm{~g}^{-1}$ ) and nitrogenous: $\mathrm{N}$ use efficiency in the fourth leaf (NUEFL, $\mathrm{g} \mathrm{g}^{-1}$ ); $\mathrm{N}$ content of the fourth leaf per area and mass basis (NCFLA and NCFL, $\mathrm{g} \mathrm{cm}^{-2}$ and dag kg${ }^{-1}$ ) and $\mathrm{N}$ content in the fourth leaf (NCFL, $\mathrm{kg} \mathrm{ha}^{-1}$ ), as well as commercial yield $\left(\mathrm{t} \mathrm{ha}^{-1}\right)$, for potato cultivars Asterix and Atlantic

\begin{tabular}{|c|c|c|c|c|c|c|c|c|c|c|}
\hline \multirow[b]{2}{*}{ Variable } & \multicolumn{5}{|c|}{ Asterix } & \multicolumn{5}{|c|}{ Atlantic } \\
\hline & Starch & TSS & RS & NRS & S/NRS & Starch & TSS & $\mathbf{R S}$ & NRS & S/NRS \\
\hline & \multicolumn{5}{|c|}{$\mathrm{mg} \mathrm{g}^{-1}$ of FM } & \multicolumn{5}{|c|}{$\mathrm{mg} \mathrm{g}^{-1}$ of $\mathrm{FM}$} \\
\hline TSS & $-0.97^{* *}$ & & & & & $-0.81^{*}$ & - & & & \\
\hline RS & $-0.99^{* *}$ & $0.96^{* *}$ & - & & & $0.35^{\mathrm{ns}}$ & $-0.07^{\mathrm{ns}}$ & - & & \\
\hline NRS & $0.07^{\mathrm{ns}}$ & 0.13 & $-0.15 n s$ & - & & $-0.83^{*}$ & $0.81^{*}$ & $-0.64^{\mathrm{ns}}$ & - & \\
\hline S/NRS & $0.35^{\mathrm{ns}}$ & $-0.44^{\mathrm{ns}}$ & $-0.23^{\mathrm{ns}}$ & $-0.74^{*}$ & - & $0.95^{* *}$ & $-0.82^{*}$ & $0.53^{\mathrm{ns}}$ & $-0.94^{* *}$ & - \\
\hline $\mathrm{CP}$ & $-0.77^{\circ}$ & $0.73^{\circ}$ & $0.70^{\circ}$ & $0.07^{\mathrm{ns}}$ & $-0.59^{\mathrm{ns}}$ & $-0.94^{* *}$ & $0.78^{*}$ & $-0.53^{\mathrm{ns}}$ & $0.91^{* *}$ & $-0.99^{* *}$ \\
\hline SPLA & $-0.80^{*}$ & $0.85^{*}$ & $0.84^{*}$ & $0.05^{\mathrm{ns}}$ & $-0.14^{\mathrm{ns}}$ & $-0.75^{\circ}$ & $0.86^{*}$ & $-0.35^{\mathrm{ns}}$ & $0.87^{*}$ & $-0.77^{*}$ \\
\hline SLAFL & $-0.54^{\mathrm{ns}}$ & $0.51^{\mathrm{ns}}$ & $0.49^{\text {ns }}$ & $0.06^{\mathrm{ns}}$ & $-0.43^{\mathrm{ns}}$ & $-0.21^{\mathrm{ns}}$ & $-0.18^{\mathrm{ns}}$ & $-0.07^{\mathrm{ns}}$ & $-0.10^{\mathrm{ns}}$ & $-0.16^{\mathrm{ns}}$ \\
\hline NUEFL & $0.94^{* *}$ & $-0.98^{* *}$ & $-0.90^{*}$ & $-0.26^{\mathrm{ns}}$ & $0.62^{\mathrm{ns}}$ & $0.94^{* *}$ & $-0.94^{* *}$ & $0.09^{\mathrm{ns}}$ & $-0.78^{*}$ & $0.88^{*}$ \\
\hline NCFLA & $-0.90^{*}$ & $0.93^{* *}$ & $0.87^{*}$ & $0.19^{\mathrm{ns}}$ & $-0.55^{\mathrm{ns}}$ & $-0.81^{*}$ & $0.87^{*}$ & $-0.17^{\mathrm{ns}}$ & $0.77^{\circ}$ & $-0.75^{\circ}$ \\
\hline NRFL & $-0.96^{* *}$ & $0.96^{* *}$ & $0.92^{*}$ & $0.14^{\mathrm{ns}}$ & $-0.59^{\mathrm{ns}}$ & $-0.91^{*}$ & $0.95^{* *}$ & $-0.27^{\mathrm{ns}}$ & $0.90^{* *}$ & $-0.90^{* *}$ \\
\hline NCFL & $-0.94^{* *}$ & $0.92^{*}$ & $0.89^{*}$ & $0.07^{\mathrm{ns}}$ & $-0.61^{\mathrm{ns}}$ & $-0.99^{* * *}$ & $0.80^{*}$ & $-0.41^{\mathrm{ns}}$ & $0.85^{*}$ & $-0.95^{* *}$ \\
\hline
\end{tabular}

FM: fresh matter mass; ns non-significant; **; * and ${ }^{\circ}$ significant by the "t" test $(\mathrm{p}<0.01)$, $(\mathrm{p}<0.05)$ and $(\mathrm{p}<0.10)$, respectively. 
A positive correlation between NUEFL with content of starch was found in this work (Table 3). Higher NUEFL was associated with the greater content of starch in the leaves, which was negatively correlated with the production of tubers. Thus, the production of tubers and NUEFL was positively correlated with the starch content in the leaf.

\section{CONCLUSIONS}

Potato plants fertilized with lower doses of $\mathrm{N}$ accumulate less TSS in the leaves than those properly fertilized. The opposite occurs with the starch content in the fourth leaf.

Cultivars presented similar response for the five doses of $\mathrm{N}$ in relation to contents of starch and TSS. However, the response to the increase in the dose of $\mathrm{N}$ for the content of RS, NRS, starch and starch/NRS in leaves of potato plants is specific for each cultivar.

In both cultivars, an inverse correlation was found between contents of starch and TSS. The correlations between contents of RS, NRS and starch/NRS with contents of starch and TSS are dependent on the specific potato cultivar.

\section{ACKNOWLEDGEMENTS}

To Fundação de Amparo à Pesquisa of the state of Minas Gerais (FAPEMIG), to the Coordenação de Aperfeiçoamento de Pessoal de Nível Superior (CAPES) and to Conselho Nacional de Desenvolvimento Científico e Tecnológico (CNPq) for granting fellowships to the students involved in this work and for the financial resources given to carry out this Project.

\section{REFERENCES}

Boussadia O, Steppe K, Zgallai H, Bem El Hadj S, Braham M, Lemeur R \& Van Labeke MC (2011) Nondestructive determination of nitrogen and chlorophyll content in olive tree leaves and the relation with photosynthesis and fluorescence parameters. Photosynthetica, 49:149-153.

Braun H, Fontes PCR, Finger FL, Busato C \& Cecon PR (2010) Carboidratos e matéria seca de tubérculos de cultivares de batata influenciados por doses de nitrogênio. Ciência e Agrotecnologia, 34:285-293.

Braun H (2012) Produtividade, índices fisiológicos e nitrogenados avaliados na planta em tempo real, influenciados pelo manejo do nitrogênio, época de cultivo e cultivar de batata. Tese de Doutorado. Universidade Federal de Viçosa, Viçosa. 230p.

Chen LI-S \& Cheng L (2003) Carbon assimilation and carbohydrate metabolism of 'Concord' grape (Vitis labrusca L.) leaves in response to nitrogen supply. Journal American Horticulture Science, 128:754-760.

Chen L-Q (2014) SWEET sugar transporters for phloem transport and pathogen nutrition. New Phytologist, 201:1150-1155.

Cruz JL, Mosquim PR, Pelacani CR, Araújo WL \& DaMatta FM (2003) Carbon partitioning and assimilation as affected by nitrogen deficiency in cassava. Photosynthetica, 41:201-207.
Dubois M, Giller KA, Hamilton JK, Rebers PA \& Smith F (1956) Colorometric method for determinations of sugars and related substance. Analytical Chemistry, 28:350-356.

Embrapa - Empresa Brasileira de Pesquisa Agropecuária (2013) Sistema brasileiro de classificação de solos. $3^{\text {a }}$ ed. Brasília, Embrapa. 353p.

Halford NG, Curtis TY, Muttucumaru N, Postles J \& Mottram DS (2011) Sugars in crop plants. Annals of Applied Biology, 158:1-25

Hirano T, Saito Y, Ushimaru H \& Michiyama H (2005) The effect of the amount of nitrogen fertilizer on starch metabolism in leaf sheath of Japonica and Indica rice varieties during the heading period. Plant Production Science, 8:122-130.

Jifon JL \& Wolfe DW (2002) Photosynthesis acclimation to elevated $\mathrm{CO} 2$ in Phaseolus vulgaris L. is altered by growth response to nitrogen supply. Global Change Biology, 8:0181027.

Jin X, Yang G, Tan C \& Zhao C (2015) Effects of nitrogen stress on the photosynthetic CO2 assimilation, chlorophyll fluorescence, and sugar-nitrogen ratio in corn. Scientific ReportsNature, 5:1-9.

McCready RMJ, Guggolz J, Silveira VV \& Owens HH (1950) Determination of starch and amylase in vegetable. Analytical Chemistry, 22:1156-1158.

Nelson NA (1944) A photometric adaptation of Somagy method for determination of glucose. Journal Biology Chemistry, 135:136-137.

Niittylä T, Messerli G, Trevisan M, Chen J, Smith AM \& Zeeman SC (2004) A previously unknown maltose transporter essential for starch degradation in leaves. Science, 303:87-89.

Osone Y, Ishida A \& Tateno M (2008) Correlation between relative growth rate and specific leaf area requires associations of specific leaf area with nitrogen absorption rate of roots. New Phytologist, 179:417-427.

Pan J, Cui K, Wei D, Huang J, Xiang J \& Nie L (2011) Relationships of non-structural carbohydrates accumulation and translocation with yield formation in rice recombinant inbred lines under two nitrogen levels. Physiologia Plantarum, 141:321-331.

Paul MJ \& Driscoll SP (1997) Sugar repression of photosynthesis: the role of carbohydrates in signalling nitrogen deûciency through source: sink imbalance. Plant, Cell and Environment, 20:110-116.

Paul MJ \& Foyer CH (2001) Sink regultation of photosynthesis. Journal of Experimental Botany, 52:1383-1400.

Robredo A, Pérez-López U, Miranda-Apodaca J, Lacuesta M, Mena-Petite A \& Muñoz-rueda A (2011) Elevated $\mathrm{CO}_{2}$ reduces the drought effect on nitrogen metabolism in barley plants during drought and subsequent recovery. Environmental and Experimental Botany, 71:399-408.

Ruuska SA, Lewis DC, Kennedy G, Furbank RT, Jenkins CLD \& Tabe LM (2008) Large scale transcriptome analysis of the effects of nitrogen nutrition on accumulation of stem carbohydrate in reproductive-stage wheat. Plant Molecular Biology, 66:15-32.

SAEG (2007) Sistema para Análises Estatísticas, Versão 9.1. Viçosa, Fundação Arthur Bernardes/UFV. CD-ROM.

Stitt M (1999) Nitrate regulation of metabolism and growth. Current Opinion Plant Biology, 2:178-186.

Stitt M (1991) Rising CO2 levels and their potential significance for carbon flow in photosynthetic cells. Plant Cell and Environment, 14:741-762. 
Wang S, Zhu Y, Jiang H \& Cao W (2006) Positional differences in nitrogen and sugar concentrations of upper leaves relate to plant $\mathrm{N}$ status in rice under different $\mathrm{N}$ rates. Field Crops Research, 96:224-234.

Weise SE, van Wijk KJ \& Sharkey TD (2011) The role of transitory starch in $\mathrm{C} 3, \mathrm{CAM}$, and $\mathrm{C} 4$ metabolism and opportunities for engineering leaf starch accumulation. Journal of Experimental Botany, 62:3109-3118.
Wingler A, Purdy S, MacLean JA \& Pourtau N (2006) The role of sugars in integrating environmental signals during the regulation of leaf senescence. Journal of Experimental Botany, 57:391399.

Zeeman SC, Smith SM \& Smith AM (2007) The diurnal metabolism of leaf starch. Biochemical Journal, 401:13-28.

Zeeman SC, Kossmann J \& Smith AM (2010) Starch: Its metabolism, evolution, and biotechnological modiûcation in plants. Annual Review Plant Biology, 61:1-26. 